\title{
Carcass quality of feedlot finished steers fed yeast, monensin, and the association of both additives
}

\author{
[Qualidade de carcaça de novilhos terminados com dietas contendo levedura, monensina \\ e associação de ambos aditivos]
}

\author{
R.C. Gomes, P.R. Leme, S.L. Silva, M.T. Antunes, C.F. Guedes
}

Faculdade de Zootecnia e Engenharia de Alimentos - USP

Duque de Caxias Norte, 225

13635-900 - Pirassununga, SP

\begin{abstract}
To evaluate the effects of the supplementation of feed additives on carcass quality in beef cattle, 72 Nellore steers $(339.5 \mathrm{~kg}, 20$-month old) were feedlot finished and fed for 91 days one of the following diets: 1) control with no additives; or added of 2) live yeast culture; 3) monensin; or 4) the association of both additives. After slaughter, renal, pelvic, and inguinal fat and hot carcass weights were recorded and carcass was split into muscle, bone, and trimmable fat. Carcass Longissimus muscle area and subcutaneous fat thickness at the $12^{\text {th }}$ rib were measured and steaks of Longisimus muscle were taken to determine meat color, shear force, drip, and cooking losses. Yeast increased carcass dressing percentage but there were no effects on hot carcass weight, Longissimus area, subcutaneous fat thickness, percentage and weight of retail cut yield and trimmings. Feed additives had no effect on carcass $\mathrm{pH}$, meat color, fat content, shear force, and drip losses. Supplementation of yeast, monensin or the association of both additives had no important effects on carcass traits and on meat quality of feedlot finished steers.
\end{abstract}

Keywords: steer, direct-fed microbial, ionophores, retail product yield, shear force, Saccharomyces cerevisiae

\section{RESUMO}

Avaliaram-se os efeitos da suplementação de aditivos alimentares sobre a qualidade de carcaça em bovinos de corte. Usaram-se 72 novilhos Nelore com média de peso de 339,5kg e 20 meses de idade, terminados em confinamento e alimentados por 91 dias com uma das quatro dietas: 1) dieta controle sem aditivos, ou com a adição de 2) leveduras vivas, 3) monensina ou 4) associação entre ambos aditivos. Após o abate, os pesos da gordura renal, pélvica e inguinal e da carcaça foram medidos e a carcaça dividida em músculos, ossos e aparas. Foram mensurados a área de olho de lombo e a espessura de gordura subcutânea sobre o músculo Longissimus na região da $12^{a}$ costela e foram obtidos bifes para a determinação da cor, força de cisalhamento e perdas por cocção e cozimento da carne. A levedura aumentou o rendimento de carcaça, mas não houve efeito dos tratamentos sobre o peso de carcaça, porção comestivel e aparas. Os aditivos não influenciaram o pH da carcaça, a cor, a gordura intramuscular, a força de cisalhamento e as perdas por exsudação da carne. A suplementação, com levedura e com monensina em associação ou separadamente, não teve efeito importante sobre a qualidade da carcaça em novilhos terminados em confinamento.

Palavras-chave: novilho, aditivo alimentar microbiano, ionóforos, força de cisalhamento, porção comestivel, Saccharomyces cerevisiae

Recebido em 5 de novembro de 2008

Aceito em 13 de abril de 2009

E-mail: rgomes@usp.br 


\section{INTRODUCTION}

Nutritional management represents one of the most important variables which drive beef production. Dietary energy in particular affects tissue depots in growing animals and, as a result, carcass traits and meat quality are also influenced (Oddy et al., 2001; Purchas et al., 2002).

Growing bulls had an increment in empty body fat content and daily energy retention of $15.3 \%$ and $15.9 \%$, respectively, when monensin was added to the diet (Daenick et al., 1982). The ionophore increases propionic acid production and decreases gases losses in the rumen (Leopoldino et al., 2007) and, consequently, body composition may be modified due to shifts in energy partition. For that reason, feed additives like monensin are likely to exert indirect effects on carcass traits. However, by presenting antibiotic property, they have been banned from animal feeding and this fact has stimulated the investigation of non antimicrobial feed additives named direct-fed microbials.

Among direct-fed microbials, live yeast culture has received particular attention of the research community. Fermentation extracts of Saccharomyces cerevisiae and Aspergillus oryzae create a favorable environment for microbial growth, stimulating L-lactate uptake by ruminal bacteria (Waldrip and Martin, 1993). As a consequence, improved dry matter intake, feed efficiency (Mir and Mir, 1994; Wallace, 1994), rumen propionic acid and total volatile fatty acids content (Arcos-Garcia et al., 2000; Miller-Webster et al., 2002), diet digestibility (Zeoula et al., 2008), and weight gain (Haddad and Goussous, 2005) may be achieved. Therefore, given that yeast culture may be useful at improving dietary energy utilization, it is reasonable to investigate its effects on meat production.

The association of antibiotics and direct-fed microbials has been poorly explored specially regarding the carcass quality. Associative effects are expected by using both additives mainly in relation to energy intake, because yeast might avoid the feed intake depression usually observed in monensin-supplemented animals (Goodrich et al., 1984). Though the efforts in order to ban antibiotics, monensin is still used by animal nutritionists working for most feedlots worldwide. Therefore, useful information may be generated by using any tool which could potentially improve monensin capacity of enhancing animal performance.

It was aimed with this work to evaluate the effects of yeast, monensin, and the association of both additives supplemented to feedlot diets on carcass traits and meat quality in Nellore steers.

\section{MATERIALS AND METHODS}

Seventy-two Nellore steers $(339.5 \mathrm{~kg}$; 20-month old) were housed in dry-lots composed of Calan Broadbent feeding doors ([48 animals] American Calan Inc., Northwood, NH, USA) and in individual pens (24 animals) being individually fed a basal diet $(2.58 \mathrm{Mcal}, 143 \mathrm{~g} \mathrm{CP} / \mathrm{kg}$, dry matter basis, Table 1) supplemented with no additives (CON), yeast culture (YEA), monensin $(\mathrm{MON})$ or an association of monensin and yeast (MON+YEA) for a 91-day period. Yeast (Saccharomyces cerevisiae, strain \#1026, 5.7 x $10^{7} \mathrm{CFU} / \mathrm{g}^{1}$ ) was incorporated into the diet at $0.6 \mathrm{~g} / \mathrm{kg}$ and monensin ${ }^{2}$ at $0.3 \mathrm{~g} / \mathrm{kg}$ (dry matter basis). Monensin-plus-yeast treated animals received the sum of amounts of both additives described above.

Table 1. Ingredient content of the experimental diet

\begin{tabular}{lc} 
Ingredients & $\begin{array}{c}\mathrm{g} / \mathrm{kg} \text { of dry } \\
\text { matter }\end{array}$ \\
\hline Ground corn & 397 \\
Soybean meal 45\% & 68 \\
Soybean hulls & 290 \\
Urea & 10 \\
Mineral salt & 10 \\
Ammonium sulphate & 3 \\
Potassium chloride & 2 \\
Lime & 10 \\
Sugarcane bagass & 210 \\
\hline
\end{tabular}

Following the end of the feeding trial, animals were slaughtered $(475.3 \pm 25 \mathrm{~kg} \quad \mathrm{BW}, \quad$ no significant difference among treatments, $\mathrm{P}>0.05$, data not shown). Weights of liver and renal

${ }^{1}$ Beef-Sacc ${ }^{\circledR}$, Alltech, Inc. - Lexington, KY, USA.

${ }^{2}$ Rumensin ${ }^{\circledR}, 10 \%$ of monensin - Elanco, Inc., Greenfield, IN, USA. 
pelvic and inguinal fat mass (RPIF) were recorded. Carcasses were weighed and immediately chilled at $0-2^{\circ} \mathrm{C}$ for 24 hours. Carcass $\mathrm{pH}$ was measured at one hour after slaughtering and 24 hours after chilling. The left side of each carcass was manually split into muscles, bones, and trimmable fat and their weights were recorded. Longissimus area (rib eye area) and fat thickness were measured between the $12^{\text {th }}$ and the $13^{\text {th }}$ ribs and steaks $(2.5 \mathrm{~cm}$ thick $)$ from this muscle were obtained for meat quality traits assessment. Hunter color $\mathrm{L}^{*}, \mathrm{a}^{*}$, and $\mathrm{b}^{*}$ values were measured using a Hunter Lab MiniScan XE colorimeter ${ }^{3}$. One steak was lyophilizated for determination of muscle ether extract content (Official..., 1990) and three more steaks were designated to tenderness, drip, and cooking loss evaluation being vacuum-packed and aged for zero, seven or 14 days in a refrigerator with an internal temperature set to 2$4^{\circ} \mathrm{C}$. As aging times were completed, samples were cooked according to the methodology of AMSA (Research..., 1995) and Warner-Bratzler shear force values (WB_SF) were determined. Cooking loss percentage (CL) was calculated as the relative weight loss by cooking compared to the initial steak weight. Drip loss percentage (DL) was calculated as the weight of exsudate presented in the aging bag after sample thawing relative to the sum of exsudate and steak weights.

Data statistical analysis considered a split plot design (with measures being repeated over time) for WB_SF, DL, and CL and was carried out using PROC MIXED from SAS/1998. Effects included in the model (main effects) were: treatment, blocks, time, and the interaction between treatment and time. Carcass traits, meat color, and crude fat content were submitted to two-way ANOVA using General Linear Models (GLM) of SAS and fixed effects included treatments and blocks (initial live weight at the feeding trial). In this case, the test HSD-Tukey was used to compare means. Effects were considered significant when $\mathrm{P}$ value was $<0.05$. Means were obtained by LSMEANS procedures.

\section{RESULTS AND DISCUSSION}

Carcass traits measured at slaughtering are shown on Table 2. No treatments effects were

${ }^{3}$ Hunter Associates Laboratory, Inc, Reston, VA. observed on RPIF, liver, and hot carcass weights $(\mathrm{P}>0.05)$. These results are similar to those obtained by Gilka et al. (1989), who observed no effects on liver weight and kidney fat in lambs fed monensin. However, animals supplemented with yeast in feedlot presented higher $(P<0.05)$ carcass dressing percentage $(56.9 \%)$ than $\mathrm{CON}$ $(55.9 \%)$ or MON+YEA animals (55.5\%). Differences between MON (56.4\%) and YEA and among $\mathrm{CON}, \mathrm{MON}$, and $\mathrm{MON}+\mathrm{YEA}$ were not statistically significant $(\mathrm{P}>0.05)$. In disagreement with these results, Fontenot and Huchetten (1993), evaluating the addition of monensin and sorbitol in feedlot diets for Angus $\mathrm{x}$ Hereford crossbred steers, observed a small decrease in carcass dressing percentage by feeding monensin. Reasons for the fact that yeast supplementation increased carcass dressing percentage are not apparent. This trait is related to animal live weight at slaughtering, cavitary fat, organs, and also hot carcass weights. Conversely, no treatments effects were observed on these traits.

No differences in rib eye area and fat thickness were observed among treatments $(\mathrm{P}>0.05)$. Results are in accordance with those showed by Greene (2002), who evaluated the effects of daily supplementation of Saccharomyces cerevisiae (0, 5 , and $20 \mathrm{~g} /$ animal of Biosaf $^{\circledR}, 8 \times 10^{9} \mathrm{CFU} / \mathrm{g}$ ) to crossbred heifers fed high grain diet in feedlot and observed no treatments effects on hot carcass weight, Longissimus fat thickness, and rib eye area. Likewise, Mir and Mir (1994) did not find effects of yeast supplementation on fat thickness and rib eye area in Hereford steers. No effects of monensin addition in feedlot diets to $1 / 4 \mathrm{Gir} 3 / 4$ Holstein steers were observed on rib eye area and fat thickness (Morais et al., 1993b).

Weight and percentage of retail cuts yield and carcass trimmable fat were similar among CON, YEA, MON, and MON+YEA groups. Results obtained by the present study are in agreement with those found by Greene (2002), who observed no effects on meat yield by feeding live yeast to crossbred heifers; and Mir and Mir (1994), who did not find any effects of yeast supplementation on meat yield in Hereford steers. Likewise no effects on retail yield and trimming percentage (Morais et al., 1993a) were observed when monensin was added in feedlot diets to $1 / 4$ Gir $3 / 4$ Holstein steers. 
Carcass quality of feedlot finished...

Table 2. Carcass traits and retail yield of Nellore steers supplemented with yeast and monensin

\begin{tabular}{|c|c|c|c|c|c|c|}
\hline & Control & Yeast & Monensin & $\begin{array}{l}\text { Monensin } \\
\text { plus Yeast }\end{array}$ & SEM & Probability \\
\hline RPIF weight $(\mathrm{kg})^{1}$ & 12.4 & 12.8 & 11.6 & 12.2 & 0.23 & 0.31 \\
\hline Liver weight $(\mathrm{kg})$ & 5.24 & 5.19 & 5.22 & 5.28 & 0.06 & 0.95 \\
\hline Hot carcass weight $(\mathrm{kg})$ & 265 & 266 & 266 & 262 & 1.75 & 0.62 \\
\hline Hot carcass dressing (\%) & $55.9 \mathrm{~b}$ & $56.9 \mathrm{a}$ & $56.4 \mathrm{ab}$ & $55.5 \mathrm{~b}$ & 0.16 & 0.01 \\
\hline Rib eye area $\left(\mathrm{cm}^{2}\right)$ & 65.7 & 66.0 & 65.5 & 67.7 & 0.76 & 0.74 \\
\hline $\begin{array}{l}\text { Longissimus fat thickness } \\
\text { (mm) }\end{array}$ & 5.8 & 6.3 & 6.4 & 5.5 & 0.35 & 0.76 \\
\hline \multicolumn{7}{|l|}{ Retail cut $^{2}$} \\
\hline Total weight $(\mathrm{kg})$ & 90.9 & 91.7 & 91.2 & 90.4 & 0.66 & 0.86 \\
\hline Percentage $(\%)^{3}$ & 70.5 & 71.5 & 70.1 & 70.7 & 0.26 & 0.30 \\
\hline \multicolumn{7}{|l|}{ Trimming $^{2}$} \\
\hline Total weight (kg) & 14.8 & 14.8 & 14.8 & 14.0 & 0.27 & 0.63 \\
\hline Percentage $(\%)^{3}$ & 10.7 & 10.0 & 11.1 & 10.7 & 0.28 & 0.54 \\
\hline
\end{tabular}

Means followed by distinct letters in the same row are statistically different by HSD-Tukey test.

${ }^{1}$ Sum of pelvic, inguinal, and kidney fat weights.

${ }^{2}$ Measurements related to the left half-carcass only (ultrasound scanned side).

${ }^{3}$ as percentage of hot carcass weight.

Carcass $\mathrm{pH}$ and meat quality traits are presented on Table 3. No differences were shown among treatments for carcass $\mathrm{pH}$ at one and 24-hour after slaughtering $(\mathrm{P}>0.05)$. Carcass ultimate $\mathrm{pH}$ is an important indicator of rigor mortis process and the results obtained may be considered adequate. Immonen et al. (2000) reported that ultimate $\mathrm{pH}$ above 5.8 is elevated and it may relate to dark-cutting, reduced shelf life (Gill and
Newton, 1981; Lawrie, 2000) and weak beef flavor (Dransfield, 1981). Color parameters (L*, $a^{*}$, and $\left.b^{*}\right)$ and fat content were not affected by additives supplementation $(\mathrm{P}>0.05)$. The results in the present study are similar to those obtained for Gilka et al. (1989), who observed no effects of monensin supplementation on meat color, fat content, and cooking losses in lambs.

Table 3. Carcass $\mathrm{pH}$ and meat quality in Nellore steers supplemented with yeast and monensin

\begin{tabular}{lcccccc}
\hline & Control & Yeast & Monensin & $\begin{array}{c}\text { Monensin } \\
\text { plus Yeast }\end{array}$ & SEM & Probability \\
\hline Carcass pH & & & & & & \\
$\quad$ 1h after slaughtering & 6.78 & 6.61 & 6.52 & 6.71 & 0.05 & 0.29 \\
$\quad$ 24h after slaughtering & 5.58 & 5.62 & 5.59 & 5.59 & 0.02 & 0.78 \\
Meat traits & & & & & & \\
$\quad$ Shear force, kg & 3.3 & 2.9 & 2.8 & 3.3 & 0.07 & 0.07 \\
$\quad$ Cooking loss, \% & 14.9 & 14.6 & 13.5 & 15.0 & 0.21 & 0.03 \\
$\quad$ Exsudation loss, \% & 2.1 & 2.2 & 2.3 & 2.5 & 0.09 & 0.61 \\
Color & & & & & & \\
$\quad L^{*}$ & 40.3 & 41.6 & 39.9 & 39.7 & 0.32 & 0.10 \\
$\quad \mathrm{a}^{*}$ & 14.4 & 14.7 & 14.9 & 14.7 & 0.13 & 0.46 \\
$\quad \mathrm{~b}^{*}$ & 12.8 & 13.0 & 13.2 & 12.6 & 0.14 & 0.42 \\
Crude fat (\%) & & & & & & \\
$\quad$ Dry matter basis & 16.76 & 16.44 & 16.39 & 16.21 & 0.33 & 0.95 \\
$\quad$ Original basis & 4.27 & 4.37 & 4.39 & 4.28 & 0.10 & 0.97 \\
\hline
\end{tabular}

Meat tenderness measured as Warner-Bratzler shear force was not affected by treatments $(\mathrm{P}>0.05)$ and no interaction between additives and time of aging were found (data not shown,
$\mathrm{P}>0.05$ ). Drip losses were not affected by treatments and no interaction was observed between aging time and feed additives $(P>0.05)$. For cooking losses, differences among CON, 
YEA, and MON were not statistically significant $(\mathrm{P}>0.05)$, though a significant interaction between treatment and aging occurred $(\mathrm{P}<0.05)$. At time 0 (no aging), MON+YEA showed larger $\mathrm{CL}$ than $\mathrm{CON}$ and MON $(\mathrm{P}<0.05)$ but did not differ from YEA $(\mathrm{P}>0.05)$. In addition, $\mathrm{CON}$, YEA, and MON did not differ from each other $(\mathrm{P}>0.05)$. After seven days of aging, $\mathrm{CON}$ showed higher $\mathrm{CL}$ than YEA $(\mathrm{P}<0.05)$ but did not differ from MON and MON+YEA $(\mathrm{P}>0.05)$. Differences among YEA, MON, and MON+YEA were not statistically significant ( $\mathrm{P}>0.05$ ). Finally, after 14 days of aging, MON showed smaller CL than CON $(\mathrm{P}<0.05)$ and did not differ from YEA and MON+YEA $(P>0.05)$.

This study was carried out due to feed additives have been largely employed in feedlot diets for finishing cattle to increase the efficiency of the production system despite of its efficacy have been poorly investigated. In addition, there are few publications concerned in evaluating the effects of additives on carcass quality and meat yield.

Data obtained in the present study suggest that no important effects on carcass and meat quality results by feeding monensin and yeast. For market places where carcass are rated according to quality and yield grades, no improvements would be obtained as the additives did not affect carcass weight, retail cut yield, and meat fat content (indicative of marbling score).

Growth patterns of protein and fat depots in the body are influenced by energy intake and metabolizability (Oddy et al., 2001; Purchas et al., 2002). Adding higher levels of grains into feedlot diets increases energy intake (Putrino et al., 2007) and consequently may modifies the growth patterns of carcass components, as well. However, in a study with Nellore bulls, Longissimus fat thickness, rib eye area, and rump fat thickness were not affected by concentrate levels upper than $40 \%$ (dry matter basis), showing that dietary effects on carcass traits seem to be small in Nellore cattle when grain content is higher than $40 \%$ (Silva et al., 2006). Therefore, it is possible that even though monensin and yeast may modify rumen fermentation patterns toward a more efficient fermentation, improving digestibility (Zeoula et al., 2008), dietary energy availability and nitrogen retention in the body (Costa et al.,
2007), this increment is not large enough to elicit changes on carcass traits when added to high energy diets like those used in the present study.

Moreover, even though animals receiving monensin and yeast have shown to benefit from an increased stability of rumen fermentation, avoiding sub acute acidosis and improving feed intake and animal performance (Wallace, 1994), beef production in Brazil particularly takes advantage of a significant availability of byproducts which can replace dietary starch without compromising weight gain, feed efficiency, and carcass quality (Henrique et al., 2004; Restle et al., 2004; Ezequiel et al., 2006a,b). Soybean hulls and citrus pulp normally comprise up to $30 \%$ of finishing diets in Brazilian feedlots. Possibly, feed additives have small effects when added to this kind of diet.

\section{CONCLUSIONS}

Yeast has been employed in ruminant nutrition because it is not an antibiotic and has shown to have some desirable properties in animal performance improvement. However, no effects of this additive on carcass traits and meat quality were observed in the present study. In this sense, it may be suggested that in some circumstances (not completely understood up to now) the use of feed additives is not necessary in feedlot diets, because they would represent additional expenses and neither improvement in beef quality nor enhancement of overall system efficiency would be accomplished. Nevertheless, further studies are necessary focusing interactions of diet ingredients and feed additives, which may be responsible for so variable results that can be observed in the literature and make difficult understanding the effects of feed additives.

\section{ACKNOWLEDGMENTS}

The authors gratefully acknowledge Fundação de Amparo à Pesquisa do Estado de São Paulo FAPESP, SP, Brazil, for the financial support and scholarship (FAPESP, 04/06324-3, 04/14881-0, 04/15622-8). 


\section{REFERENCES}

ARCOS-GARCIA, J.L.; CASTREJÓN, F.A.; MENDOZA, G.D. et al. Effect of two commercial yeast cultures with Saccharomyces cerevisiae on ruminal fermentation and digestion in sheep fed sugar cane tops. Livest. Prod. Sci., v.63, p.153-157, 2000.

COSTA, P.B.; QUEIROZ, A.C.; RODRIGUES, M.T. et al. Desempenho de novilhas leiteiras sob manejo para crescimento compensatório recebendo suplementação com ionóforo. Rev. Bras. Zootec., v.36, p.461-470, 2007.

DAENICKE, R.; ROHR, K., OSLAGE, H.J. Effect of monensin on rumen fermentation, performance, and body composition of growing bulls. Livest. Prod. Sci., v.8, p.479-488, 1982.

DRANSFIELD, E. Eating quality of DFD beef. In: HOOD, D.E.; TARRANT, P.V. (Eds). The problem of dark-cutting in beef. Amsterdam: Martinus Nijhoff Publishers, 1981. p.344-358.

EZEQUIEL, J.M.B.; GALATI, R.L.; MENDES, A.R. et al. Desempenho e características de carcaça de bovinos Nelore em confinamento alimentados com bagaço de cana-de-açúcar e diferentes fontes energéticas. Rev. Bras. Zootec., v.35, p.2050-2057, 2006a.

EZEQUIEL, J.M.B.; SILVA, O.G.C.; GALATI, R.L. et al. Desempenho de novilhos Nelore alimentados com casca de soja ou farelo de gérmen de milho em substituição parcial ao milho moído. Rev. Bras. Zootec., v.35, p.569$575,2006 b$.

FONTENOT, J.P.; HUCHETTE, H.M. Feeding sorbitol alone or in combination with monensin to finishing cattle. J. Anim. Sci., v.71, p.545-551, 1993.

GILKA, J.; JELINEK, P.; JANKOVÁ, B. et al. Carcass traits and meat quality of male lambs fed monensin or lasalocid. Meat Sci., v.25, p.265$272,1989$.

GILL, C.O.; NEWTON, K.G. Microbiology of DFD beef. In: HOOD, D.E.; TARRANT, P.V (Eds). The problem of dark-cutting in beef. Amsterdam: Martinus Nijhoff Publishers, 1981. p. 305-321.

GOODRICH，R.D.; GARRETT，J.E.; GAST, D.R. et al. Influence of monensin on the performance of cattle. J. Anim. Sci., v.58, p.1484-1498, 1984.

GREENE, W. Use of Saccharomyces cerevisiae in beef cattle. In: SIMPOSIO GOIANO SOBRE MANEJO E NUTRIÇÃO DE BOVINOS DE CORTE, 4., 2002, Goiânia. Proceedings... Goiânia: CBNA, 2002. p.79-96.

HADDAD, S.G.; GOUSSOUS, S.N. Effect of yeast culture supplementation on nutrient intake, digestibility and growth performance of Awassi lambs. Anim. Feed Sci. Technol., v.118, p.343348, 2005.

HENRIQUE, W.; SAMPAIO, A.A.M.; LEME, P.R. et al. Desempenho e características de carcaça de tourinhos Santa Gertrudes confinados, recebendo dietas com alto concentrado e níveis crescentes de polpa cítrica peletizada. Rev. Bras. Zootec., v.33, p.463-470, 2004.

IMMONEM, K.; RUUSUNEN, M.; HISSA, K. et al. Bovine muscle glycogen concentration in relation to finishing diet, slaughter and ultimate pH. Meat Sci., v.55, p.25-31, 2000.

LAWRIE, R.A. Physiological stress in relation to dark-cutting beef. J. Sci. Food Agric., v.9, p.721727, 2000.

LEOPOLDINO, W.M.; LANA, R.P.; EIFERT, E.C. et al. Avaliação de ionóforos pela técnica de perda do potássio celular e produção de gases in vitro. Arq. Bras. Med. Vet. Zootec., v.59, p.15161522, 2007.

MILLER-WEBSTER， T.; HOOVER， W.H.; HOLT, M. Influence of yeast culture on ruminal microbial metabolism in continuous culture. $J$. Dairy Sci., v.85, p.2009-2014, 2002.

MIR, Z.; MIR, P.S. Effect of the addition of live yeast (Saccharomyces cerevisiae) on growth and carcass quality of steers fed high-forage or high grain diets and on feed digestibility and in situ degradability. J. Anim. Sci., v.72, p.537-545, 1994.

MORAIS, C.A.C.; FONTES, C.A.A., LANA, R.P. et al. Influência da monensina sobre a composição física e química da carcaça de bovinos castrados e não castrados. Rev. Bras. Zootec., v.22, p.952-959, 1993a.

MORAIS, C.A.C.; FONTES, C.A.A.; LANA, R.P. et al. Influência da monensina sobre o rendimento de carcaça e de seus cortes básicos e outras características, em bovinos castrados e 
não castrados. Rev. Bras. Zootec., v.22, p.72-80, $1993 b$.

ODDY, V.H.; HARPER, G.S.; GREENWOOD, P.L. et al. Nutritional and developmental effects on the intrinsic properties of muscles as they relate to the eating quality of beef. Aust. J. Exp. Agric., v.41, p.921-942, 2001.

OFFICIAL methods of analysis. 15.ed. Washington: AOAC, 1990.1422p.

PURCHAS, R.W.; BURNHAM, D.L.; MORRIS, S.T. Effects of growth potential and growth path on tenderness of beef longissimus muscle from bulls and steers. J. Anim. Sci., v.80, p.3211-3221, 2002.

PUTRINO, S.M.; LEME, P.R.; SILVA, S.L. et al. Digestibilidade aparente de dietas com níveis crescentes de concentrado em novilhos Brangus e Nelore. Arq. Bras. Med. Vet. Zootec., v.59, p.406-413, 2007.

RESEARCH guidelines for cookery, sensory evaluation and instrumental tenderness measurements of fresh meat. Chicago, IL: American Meat Science Association, 1995. 47p.
RESTLE, J.; FATURI, C.; ALVES FILHO, D.C. et al. Substituição do sorgo por casca de soja na dieta de novilhos terminados em confinamento. Rev. Bras. Zootec., v.33, p.1009-1015, 2004.

SILVA, S.L.; LEME, P.R.; PUTRINO, S.M. et al. Alterações nas características de carcaça de tourinhos Nelore, avaliadas por ultra-som. Rev. Bras. Zootec., v.35, p.607-612, 2006.

WALDRIP, H.M.; MARTIN, S.A. Effects of an Aspergillus oryzae fermentation extract and other factors on lactate utilization by the ruminal bacterium Megasphaera elsdenii. J. Anim. Sci., v.71, p.2770-2776, 1993.

WALLACE, R.J. Ruminal microbiology, biotechnology and ruminant nutrition: progress and problems. J. Anim. Sci., v.72, p.2992-3003, 1994.

ZEOULA, L.M.; BELEZE, J.R.F.; GERON, L.J.V. et al. Digestibilidade parcial e total de rações com a inclusão de ionóforo ou probiótico para bubalinos e bovinos. Rev. Bras. Zootec., v.37, p.563-571, 2008. 